\title{
研究時評
}

\section{アメリカ合衆国における Kaufman Assessment Battery for Children に関する研究動向}

\author{
青 山 真 二
}

\section{I . はじめに}

Kaufman Assessment Battery for Children (K ABC) は、1983 年に Kaufman A. S. らによって開発 された「子供のための心理・教育アセスメントバッテ リー」である。この K-ABC の特徴は、認知心理学と 神経心理学の知見に基づく同時処理および継次処理と いう認知処理過程の測定にある。子供の課題解決にお ける認知処理過程の特徵を明確にすることにより、教 育計画や指導方法に直結するアセスメントバッテリー として、また研究の一手段として $\mathrm{K}-\mathrm{ABC}$ が作られて いる。

わが国では、1993 年に松原らによって標準化がなさ れ、K-ABCの利用がまさに始まったばかりと言える。 こうした状況の中で、 $\mathrm{K}-\mathrm{ABC}$ の開発から既に 12 年目 を迎えるアメリカにおいて、その研究動向を調べるこ とは、今後のわが国における $\mathrm{K}-\mathrm{ABC}$ の活用に重要な 示唆を与えてくれるものと考える。

\section{II . 研究の目的と方法}

本研究では、アメリカでの $\mathrm{K}-\mathrm{ABC}$ に関する研究動 向（K-ABCについての研究または $\mathrm{K}-\mathrm{ABC}$ を用いた 研究）を明らかにするために、教育や心理学・医学等 に関する雑誌で発表された論文をいくつかのカテゴ リーに分類し、その対象や内容について分析するもの である。本研究の対象論文は、UCLA (University of California Los Angeles) で採用している『PsychINFO Database』 (by the American Psychological Association）を用いて検索された論文である。検索で 使用されたキーワードは『Kaufman Assessment Battery for Children』及び 『Simultaneous Processing and Sequential Processing』である。また検索の対象 期間は、 K-ABC が作成された 1983 年から 1993 年ま での 11 年間である。これらのキーワードと条件で検索

$\mathrm{K}-\mathrm{ABC}$ センター
された論文数は 298 文献で、その内、学位論文や書籍 及び英語以外で書かれた論文を除く206 文献につい て、その分類と分析を試みるものである。

\section{III. 結 果}

1. $\mathrm{K}-\mathrm{ABC}$ に関連する年度別研究数の推移

Psych-INFO Database で検索された 206 文献の年 度別研究数は Table 1 に示す通りである。K-ABC が 作られた翌年の 84 年から 90 年まで、 88 年をピークに 毎年 20 文献以上の論文が発表されている。しかしなが ら、91 年以後は 10 文献前後の発表にとどまっている。 また、これら 206 文献の内、168 文献が実際に K-ABC を実施しており、残りの 38 文献はテストに対するレ ビューや標準化サンプルを用いた研究となっている。 こうしたレビューや標準化サンプルを用いた研究は、 $\mathrm{K}-\mathrm{ABC}$ が作られた翌年の 84 年に最も多く、それ以後 年々少なくなり、92 年以後はそうした文献がみられな くなっている。

\section{2. 研究内容別分類}

K-ABCに関連した 206 文献について、Smith ら $\left(1989^{37}\right)$ の「Annoted Bibliography of K-ABC Research Studies」を参考に、A〜K までの 11 のカテ ゴリーに分類した。それぞれのカテゴリーとそのカテ ゴリーにおける年度別研究数は Table 2 に示す通りで ある。

全カテゴリーの中で最も多い研究が、 $\mathrm{K}-\mathrm{ABC}$ の妥 当性や信頼性・安定性に関するもので、全体の約 $24 \%$ を占めている。また因子分析や他検査との相関に関す る研究も含めると 90 文献にものぽ、心理検查の測定 に関する統計学的研究が全体の 44\%を占めているこ とになる。次に多い研究が K-ABC の障害児への適用 に関する論文で 22 文献みられ、全体の $11 \%$ となって いる。こうした障害児への適用に関する論文は、 $\mathrm{K}$ -ABC の妥当性等に関する論文同様、ほほ毎年の様に コンスタントに発表されている。次いで多いのが、レ 
Table $1 \mathrm{~K}$-ABCに関連した年度別研究総数とK-ABCを実施している研究数

\begin{tabular}{|c|c|c|c|c|c|c|c|c|c|c|c|c|}
\hline & 83年 & 84年 & 85年 & 86年 & 87年 & 88年 & 89年 & 90 年 & 91年 & 92年 & 93年 & 計 \\
\hline $\mathrm{K}-\mathrm{ABCに}$ 関連した年度別研究総数 & 5 & 26 & 23 & 27 & 20 & 31 & 21 & 20 & 11 & 13 & 9 & 206 \\
\hline K-ABCを実施している研究数 & 4 & 9 & 17 & 24 & 16 & 29 & 16 & 16 & 10 & 13 & 9 & 168 \\
\hline
\end{tabular}

Table $2 \mathrm{~K}-\mathrm{ABCに}$ 関連した研究の内容別研究数

\begin{tabular}{|c|c|c|c|c|c|c|c|c|c|c|c|c|}
\hline & 83 年 & 84 年 & 85 年 & 86年 & 87 年 & 88年 & 89年 & 90 年 & 91年 & 92年 & 93年 & 計 \\
\hline A. Factor Analytic Studies & 0 & 2 & 1 & 5 & 3 & 2 & 0 & 1 & 0 & 0 & 2 & 16 \\
\hline $\begin{array}{l}\text { B. Validities, Reliabilities, Stabilities } \\
\text { Studies }\end{array}$ & 1 & 6 & 7 & 4 & 6 & 10 & 4 & 4 & 2 & 5 & 1 & 50 \\
\hline C. Correlationship with others & 0 & 1 & 5 & 5 & 2 & 5 & 2 & 3 & 1 & 0 & 0 & 24 \\
\hline D. Review, Evaluation of $\mathrm{K}-\mathrm{ABC}$ & 1 & 8 & 3 & 3 & 1 & 0 & 0 & 1 & 0 & 0 & 0 & 17 \\
\hline $\begin{array}{l}\text { E. Studies about Characters of han- } \\
\text { dicapped Children }\end{array}$ & 1 & 0 & 1 & 2 & 4 & 4 & 2 & 2 & 2 & 3 & 1 & 22 \\
\hline $\begin{array}{l}\text { F. Studies about Characters on } \\
\text { Racial difference }\end{array}$ & 0 & 1 & 0 & 2 & 1 & 1 & 3 & 0 & 1 & 1 & 1 & 11 \\
\hline $\begin{array}{l}\text { G. Studies about Characters of Non- } \\
\text { handicapped Children }\end{array}$ & 0 & 0 & 1 & 1 & 0 & 1 & 1 & 1 & 1 & 0 & 0 & 6 \\
\hline $\begin{array}{l}\text { H. Studies Exploring Neuropsy- } \\
\text { chological Relationships }\end{array}$ & 1 & 1 & 2 & 3 & 1 & 1 & 0 & 1 & 0 & 0 & 0 & 10 \\
\hline $\begin{array}{l}\text { I. Studies about Teaching and } \\
\text { Remediation }\end{array}$ & 0 & 1 & 0 & 1 & 0 & 1 & 0 & 2 & 0 & 1 & 1 & 7 \\
\hline J. Studies about assessment & 0 & 2 & 2 & 0 & 0 & 2 & 2 & 1 & 0 & 0 & 0 & 9 \\
\hline K. Others & 1 & 4 & 1 & 1 & 2 & 4 & 7 & 4 & 4 & 3 & 3 & 34 \\
\hline 研 究 総 数 & 5 & 26 & 23 & 27 & 20 & 31 & 21 & 20 & 11 & 13 & 9 & 206 \\
\hline
\end{tabular}

ビュー等の $\mathrm{K}-\mathrm{ABC}$ に対する評価に関する論文で 17 文献みられる。しかし、この内の約半数に当たる 8 文 献が 84 年に発表されたもので、これは“The Journal of Special Education”でK-ABCの特集号が組まれ たために、このような突出した数となっている。この 他のカテゴリーでは、全体の5\%以下のものであるが、 他民族や少数民族への $\mathrm{K}-\mathrm{ABC}$ の適用に関する論文 が 11 文献、神経心理学的研究が 10 文献、診断等に関 する論文が 9 文献、指導や治療に関する文献が 7 文献、 健常児の認知特性等に関する論文が 6 文献となってい る。この他、数が少ないために（医学や幼児発達に関 係した論文等)、一つのカテゴリーとしてまとめられな かった論文 34 文献が「その他」としてまとめられてい る。

Table 2 に示された 11 のカテゴリーの内、全体の

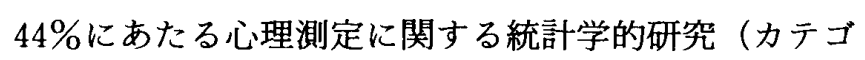
リーA〜C）の研究概要は以下の通りである。

\section{A. 因子分析に関寸る研究}

K-ABCにおける因子分析的研究は、Table 2 に示 されるように、206 文献中 16 文献である。標準化サン プルを用いた研究では、年齢別、性別、人種別にその 構成概念妥当性が確認されており、 $\mathrm{K}-\mathrm{ABC}$ の基本と なる因子が同時処理と継次処理の 2 因子及び習熟尺度 を加えた 3 因子と強い相関があることが明らかにされ ている (Kaufman and Kamphaus, 1984 ${ }^{18)}$; Keith and Dunbar, 1984 ${ }^{21)}$; Willson, Reynolds, Chatman, and Kaufman, 198541) ; Kamphaus and Kaufman, $1986^{14)}$; Strommen, 1988 ${ }^{39)}$ )。

また他検査との結合因子分析では、Wechsler lntelligence Scale for Children Revised (WISC-R) や 
McCarthy Scale との分析が行われ、強い相関が認め られている (Kaufman and McLean, 1987'16); Moon, Ishikuma, and Kaufman, $1987^{28)}$; Keith and Novak, $\left.1987^{19)}\right)$ 。WISC-R の第 1 因子である言語理解は K $-\mathrm{ABC}$ の習熟尺度との関係が深く、第 2 因子の知覚的 体制化は同時処理と、また第 3 因子の被転導性からの 開放は継次処理と類似していることが明らかになって いる。また、最近では Kaufman (1993 $\left.{ }^{15)}\right)$ が、Kaufman Adolescent and Adult Intelligence Test (KAIT) $と$ の結合因子分析を行なっており、両検査がわずかに重 なり合う 6 つの説明可能な因子を見いだしている。

この他、学習障害児や学習上の何等かの問題を抱え る子供達を対象とした場合の因子分析研究も行われて いる (Kaufman and McLean, 1986 ${ }^{17)}$; Keith, $1986^{20)}$; Good and Lane, 1990')。

B．信頼性や妥当性等に関する研究

$\mathrm{K}-\mathrm{ABC}$ の信頼性や妥当性等に関する研究は、206 文献中 50 文献にのほり、 $\mathrm{K}-\mathrm{ABC}$ に関する研究ジャン ルの中でもっとも多くなされている領域である。また その多くが $\mathrm{K}-\mathrm{ABC}$ のテストとしての妥当性や信頼 性を裹づけるものであり、その内訳は以下の通りであ る。

$\mathrm{K}-\mathrm{ABC}$ の妥当性に関する文献は 39 文献で、他のテ ス卜との併存的妥当性 (Concurrent Validity) や構成 概念妥当性 (Construct Validity) に関する文献がそれ ぞれ 11 文献ずつ、予測的妥当性(Predictive Validity) に関する文献が 7 文献、この他に収束的妥当性 (Convergent Validity) や外部妥当性 (External Validity) 等に関する文献が 11 文献となっている。これらの研究 では、WISC-Rや McCarthy Scale およびStanford -Binet Intelligence Scale IV（SBIS-IV）との相関が 高く、それらのほとんどが、Bracken $\left(1987^{3)}\right)$ の論文 に示されるように、 $\mathrm{K}-\mathrm{ABC}$ の妥当性を支持しており、 その対象が白人のみならず黒人やスペイン系の移民等 に対してもその妥当性が示されている。また健常児の みならず学習障害児や学習上の何等かの問題を持って いる子供達においても、その妥当性が確かめられてい る。しかし、これらの結果とは反対に、K-ABCの予測 的妥当性において、メキシコからの移民に対する偏見 の証拠となるデータを示したValencia and Rankin $\left(1988^{40}\right)$ の研究やスコットランドの聴覚障害児に対し ては、 $\mathrm{K}-\mathrm{ABC}$ の妥当性が得られなかったという Gibbins $\left(1989^{5}\right)$ ) の研究、また外傷性脳障害児に対する K - $\mathrm{ABC}$ の解釈には十分注意が必要であるといった Donder $\left(1992^{4}\right)$ のやや否定的な結果を示す研究もみ
られる。

$\mathrm{K}-\mathrm{ABC}$ の信頼性に関する論文は 4 文献みられる が、人種別・年齢別の比較の全てにおいて高い信賴性 を示している (Harrington, Mcvey, and Follett, $1985^{8)}$; Siegel and Piotrowski, 1985 ${ }^{36)}$; Matazow, Kamphaus, Stanton, and Reynolds, $1991^{26)}$; Hernandes and Willson, 1992 ${ }^{10)}$ )。

またテストの安定性に関する論文も 4 文献みられる が、幼稚園児における縦断的研究やリスク児および低 収入家庭の幼稚園児において、その安定性が示されて いる (Smith, Balin, and Stovall, 1988 ${ }^{38)}$; Lyon and Smith, 198724) ; Lamp and Krohn, 1990 ${ }^{23)}$; Bracken, Howell, and Harrison, 19912) $)$ 。

C . 他検查との相関に関する研究

ここで取り扱う「他検查との比較」という研究力テ ゴリーは、Table 2 に示した $\mathrm{K}-\mathrm{ABC}$ の妥当性や信頼 性・安定性および因子分析的研究を除く、他検査との 比較研究についてまとめたものである。24 文献中、15 文献が健常児または優秀児を対象とした研究で、残り 9 文献が障害児またはその可能性のある子供を対象に 行なった研究である。

WISC-R との一連の比較研究を行なっている Naglieri ら $\left(1985^{31)}, 1986 \mathrm{a}^{30)}, 1986 \mathrm{~b}^{29)}\right)$ は、WISC-R の全 検査 $\mathrm{IQ}$ と $\mathrm{K}-\mathrm{ABC}$ の認知処理尺度との相関が高いこ とを確認しており、特に黒人のこどもにおいて両検査 の得点差が著しく小さいことを見いだしている。しか しながら優秀児においては、WISC-R の全検査 IQ が $\mathrm{K}-\mathrm{ABC}$ の認知処理尺度の得点よりも有意に高いこと を見いだしており、この結果の理由として、 $\mathrm{K}-\mathrm{ABC}$ が WISC-R よりも難しい設問が少ないことを指摘して いる。また Naglieri (1985 ${ }^{32)}$ ) は、Mc Carthy Scales や Peabody Individual Achievement Test との比較 も行なっており、WISC-R 同様にそれらとの高い相関 を見いだしている。

Stanford-Binet IV と K-ABCの比較研究では、 Hendershottら $\left(1990^{11)}\right)$ の研究や Rothlisberg ら $\left(1991^{34)}\right)$ の研究がみられるが、共に両テストの相関が 高く、両テストの得点にも有意な差がみられなかった ことを指摘している。一方 $\mathrm{K}-\mathrm{ABC}$ の習熟尺度と Peabody Picture Vocabulary Test-R (PPVT-R) と の比較を行なった Mcloughlin ら $\left(1984^{27)}\right)$ は、両テス トが異なった因子も測定していることに注意しなけれ ばならないと警告している。この他に、幼児のパーソ ナリティーと認知処理能力との関係をみるために、 Junior Eysenck Personality Inventory と $\mathrm{K}-\mathrm{ABC} の$ 
Table $3 \mathrm{~K}$-ABCを実施している研究数の対象者別（被保険者）内訳

\begin{tabular}{|c|c|c|c|c|c|c|c|c|c|c|c|c|}
\hline & 83年 & 84年 & 85年 & 86年 & 87年 & 88年 & 89年 & 90 年 & 91年 & 92年 & 93年 & 計 \\
\hline a. Attention Deficit Disorder & 0 & 0 & 0 & 1 & 0 & 0 & 0 & 1 & 0 & 0 & 0 & 2 \\
\hline $\begin{array}{l}\text { b. Emotional/Behavioral Problem, } \\
\text { Autism }\end{array}$ & 0 & 0 & 1 & 1 & 0 & 0 & 1 & 0 & 1 & 2 & 0 & 6 \\
\hline c. Gifted & 0 & 1 & 3 & 3 & 0 & 1 & 2 & 0 & 0 & 0 & 0 & 10 \\
\hline $\begin{array}{l}\text { d. Hearing lmpaired, Communica- } \\
\text { tion/Language Disorders }\end{array}$ & 0 & 0 & 0 & 1 & 0 & 2 & 1 & 1 & 2 & 0 & 1 & 8 \\
\hline $\begin{array}{l}\text { Learning Disabilities, Reading } \\
\text { Disabled }\end{array}$ & 2 & 2 & 5 & 4 & 3 & 10 & 4 & 2 & 1 & 3 & 1 & 37 \\
\hline f. Mentally Retarded & 0 & 1 & 2 & 0 & 2 & 1 & 0 & 0 & 0 & 2 & 0 & 8 \\
\hline g. Other Disease & 0 & 0 & 1 & 2 & 3 & 0 & 1 & 2 & 2 & 4 & 1 & 16 \\
\hline h. Minority Student & 0 & 2 & 0 & 5 & 2 & 3 & 2 & 0 & 0 & 3 & 3 & 20 \\
\hline I. Nonhandicapped Student & 1 & 3 & 5 & 4 & 5 & 3 & 2 & 3 & 2 & 1 & 3 & 32 \\
\hline j. Nonhandicapped Preschooler & 1 & 1 & 1 & 3 & 2 & 9 & 2 & 7 & 5 & 0 & 0 & 31 \\
\hline k. At-risk Child & 0 & 0 & 0 & 1 & 1 & 3 & 1 & 2 & 0 & 2 & 0 & 10 \\
\hline 研 究 総 数 & 4 & 9 & 17 & 24 & 16 & 29 & 16 & 16 & 10 & 13 & 9 & 168 \\
\hline $\begin{array}{l}\text { (備考) } \\
\text { 主要な研究対象が複数の場合の研究数 }\end{array}$ & $(0)$ & $\begin{array}{l}(1) \\
E-F\end{array}$ & $\begin{array}{l}(1) \\
E-F\end{array}$ & $\begin{array}{r}(1) \\
\mathrm{I}-\mathrm{J}\end{array}$ & $\begin{array}{c}(2) \\
I-J \\
I-J\end{array}$ & $\begin{array}{r}(3) \\
I-J \\
I-J \\
I-J\end{array}$ & $(0)$ & $\begin{array}{r}(2) \\
I-J \\
I-J\end{array}$ & $\begin{array}{r}\text { ( } 3 \text { ) } \\
\text { B-D } \\
\text { E-G } \\
\text { I-J }\end{array}$ & $\begin{array}{c}(3) \\
\mathrm{E}-\mathrm{K} \\
\mathrm{F}-\mathrm{G} \\
\mathrm{B}- \\
\mathrm{E}-\mathrm{F}\end{array}$ & $(0)$ & \\
\hline
\end{tabular}

比較を行なった Saklofske $\left(1985^{35)}\right)$ の研究などもみら れる。

障害児を対象に行なった研究でも、WISC-Rや McCarthy Scale, Stanford-Binet IV等の知能検査と $\mathrm{K}-\mathrm{ABC}$ の比較が行なわれ、健常児同様に高い相関が 確認されている (Naglieri, 1985 ${ }^{33)}$; Klanderman, Perney, and Kroeschell, 1985 ${ }^{22)}$; Lyon and Smith, $1986^{25)}$; Zucker and Riordan, 198842), Heath and Obrzut，1988 9) 。また学習障害児におけるStanford Achievement Test (SAT) やWoodcock-Johnson Test of Academic Achievement (W-J) との一連の比 較研究を行ったHooperら $\left(1987^{13}, 1988^{12)}\right)$ は、K -ABCのアチーブメント因子が、SATの「読み」「算 数」語彙」と有意な相関があることを見いだした。ま た $\mathrm{K}-\mathrm{ABC}$ の継次処理尺度の得点が $\mathrm{W}-\mathrm{J} の 「$ 読み」や 「算数」の得点と有意に関係があり、同時処理尺度の 得点は、W-Jの「算数」や「知識」と有意な相関があ ることを見いだしている。またこの他に、学習障害児 におけるBasic Achievement Skills Individual Screener (BASIS) や注意欠陷多動障害児における
Beery Developmental Test と K-ABC との関係を調 べた研究等もみられる (Grant, Ilai, Nussbaum, and Bigler, 19907) ; Blount and Whorton, 1990')

\section{K-ABC の対象者別文献数}

$\mathrm{K}-\mathrm{ABC}$ を実際に行なっている研究は、Table 1 に 示すように、206 文献中 168 文献みられる。この 168 文 献について年度別に、 $\mathrm{a} \sim \mathrm{k}$ までの 11 の対象者力テゴ リーで分類を行なった。その対象者別文献数は Table 3 に示す通りである。またその分類にあたっては、研究 の対象者が複数のカテゴリーにまたがる場合、それぞ れのカテゴリーにカウントし、Table 3 の備考欄にそ の研究数を示した。しかし、明らかに実験のコントロー ル群として位置づけられた対象者はカウントせず、研 究の主目的を満たす対象者のみで分類を行なった。

$\mathrm{K}-\mathrm{ABC}$ を実施している研究の中で最も多い対象者 カテゴリーは学習障害児で、総計が 37 文献にのほって いる。次いで健常学齢児を対象とした研究が 32 文献、 健常学齢前児が 31 文献、他民族または少数民族の学齢 児を対象にした研究が 20 文献、そして優秀児とリスク 児がそれぞれ 10 文献ずつとなっている。この他では、 
聴覚・言語障害と精神発達遅滞がそれぞれ 8 文献ずつ、 情緒障害や自閉症が 6 文献、注意欠陥障害が 2 文献と なっている。

\section{IV. 考 察}

Table 1 に示される K-ABCに関連した研究数の年 度別推移は、 $\mathrm{K}-\mathrm{ABC}$ に対する関心度という側面から も解釈できる。すなわち、 $\mathrm{K}-\mathrm{ABC}$ が作られた翌年の 84 年には、新しい心理・教育アセスメントバッテリー として多くの関心が寄せられ、数多くのレビューで紹 介されている。しかし実際に $\mathrm{K}-\mathrm{ABC}$ を使用した研究 は、 2 年後の 85 年から急速に増え始め、ピークの 88 年 には 29 文献もの研究が行なわれるようになり、 $\mathrm{K}$ -ABCに対する強い関心は 90 年まで続いたと解釈で きる。つまり 84 年から 90 年までに、心理・教育アセ スメントバッテリーとしての信頼性や妥当性を裏づけ る研究がなされ、新しい心理テストとして地位を確立 したと考えられる。91 年以降は、毎年 10 文献前後の研 究が発表されているが、それまでにみられるような $\mathrm{K}$ - $\mathrm{ABC}$ に対する評価のための基礎研究から、 $\mathrm{K}-\mathrm{ABC}$ を利用した応用的研究が増えるようになってきてい る。このことは、Table 2 に示されるように、91 年以 降の年度別研究総数が 10 文献前後の内、3〜 文献が その他の研究に分類されており、また他検査との相関

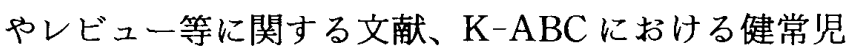
の特性や神経心理学的な実験的研究がみられないこと もその現れの一つであると考えられる。

Table 2 に示された内容別研究数では、因子分析的 研究を始め、妥当性や信頼性、他検査との相関等に関 する統計学的研究が全研究数の $44 \%$ 占めているこ とは、 $\mathrm{K}-\mathrm{ABC}$ が従来の心理検査とは異なる視点で作 られた新しい発想の心理検査である以上、当然のこと であろう。逆に言えば、K-ABCについて様々な視点か らその妥当性や信頼性を統計学的に分析していること になる。

$\mathrm{K}-\mathrm{ABC}$ に対する統計学的な妥当性や信頼性に関す る研究は、健常児を対象とした場合、そのほとんどが 心理アセスメントバッテリーとしての妥当性と信頼性 を裏づけるものであった。一方、障害児を対象とした 場合の統計学的研究でも、学習障害児を対象とした研 究を中心に 33 文献みられるが、健常児同様に、テスト の妥当性と信頼性を裏づける結果を示す研究が多い。 しかし障害の重い子や聴覚障害児・脳障害児といった 子供を対象とした場合の $\mathrm{K}-\mathrm{ABC}$ は、十分な妥当性が 得られなかったという研究もいくつかみられる。この
ことは、 $\mathrm{K}-\mathrm{ABC}$ の適用範囲やその解釈について十分 注意しなければならないことを示すものであり、また それと同時に学習障害児以外の障害児への適用に関す る研究が今後さらに必要となることを示すものであ

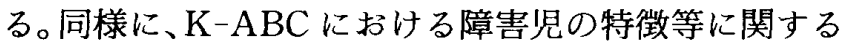
研究でも、22 文献中 8 文献が学習障害児を対象とした もので、その他の障害については自閉症児や精神発達 遅滞児・聴覚言語障害児等において、それぞれ 2 文献 前後見られるだけとなっている。これは学習障害児が 他の障害児に比べて、テストの実施が容易であるとい うことも、こうした結果の一因と思われる。しかしそ れ以上に、増大する学習障害児に対して、その対応を 模索しているアメリカの特殊な教育事情が大きく影響 しているように思われる。

このように学習障害児や健常児を対象とした心理ア セスメントバッテリーとしての基礎的研究は数多くな されているが、 $\mathrm{K}-\mathrm{ABC}$ の大きなねらいである「教育に 直結した」という具体的な $\mathrm{K}-\mathrm{ABC}$ の利用に関する研 究は、この 11 年間で 7 文献しかみられない。この事実 は大変大きな意味をもっていると思われる。つまり、 $\mathrm{K}-\mathrm{ABC}$ が従来の知能検査のように、診断だけに留ま るものなのか、または実際の指導に本当に役だてられ るものなのかを見極めるには、教育における $\mathrm{K}-\mathrm{ABC}$ の利用に関する研究が示されなければならないからで ある。勿論、雑誌等に発表された文献の数だけで、 $\mathrm{K}$ -ABCが奏際の教育にあまり利用されていないと結論 づけることはできないが、その可能性が存在すること は、現在のアメリカの教育事情からも推測できる。ま ず第 1 に黒人への偏見という問題から、知能検查の奏 施に関連した訴訟問題が多発しており、カリフォルニ ア州では K-ABC を含む全ての知能検查に対して、そ の実施に制限が加えられている状況にある。第 2 は、 $\mathrm{K}-\mathrm{ABC}$ のような心理テストはサイコロジストしか実 施できず、テストを実施するスクールサイコロジスト と指導を行なう教師との連携が形式的なものになりが ちで、検査結果を積極的に指導と結び付けることが難 しいことにある。第 3 は、学習障害児を指導する多く の教師は、健常児との統合教育を前提にしているため、 指導目標やカリキュラムの作成において、BASIS 等の アチーブメントテスト（教師が実施できる）を利用し ていることが多い。このようにアメリカの教育現場で は、K-ABCの利用が難しい状況にあるため、そうした $\mathrm{K}-\mathrm{ABC}$ の利用に関する研究が少ないものと思われ る。

Table 3 に示した対象者別研究数では、前述の通り、 
学習障害児を対象とした研究が 37 文献ともっとも多 く、リスク児を含めた障害児対象の研究総数は 81 文献 で、全研究数の $48 \%$ を占めている。このことからも $\mathrm{K}$ -ABCがその対象として、障害児を健常児と同等に位 置づけていることが理解できる。しかしながら障害の 程度は、学習障害児に代表されるように軽度なものが ほとんどである。また障害児のみならず優秀児におけ る研究も 10 文献みられることから、 $\mathrm{K}-\mathrm{ABC}$ が単に学 習でのつまづきだけをその測定の対象にしているので はなく、様々な子供の問題解決における認知処理形態 を測定しょうとしていることがこのことからも推測さ れる。

また、Table 2 に示された $\mathrm{K}-\mathrm{ABC}$ における障害児 の特徴に関する 22 文献を年度別にみると、80 年代は 学習障害児やリスク児の研究がほとんどであるが、90 年以降は学習障害児やリスク児の研究は全くみられ ず、聴覚言語障害児や自閉症児・注意欠陥多動障害児・ 脆弱 $\mathrm{X}$ 症候群といつた様々な障害児について研究が行 なわれるようになっている。ただ内容的には、ほとん どが $\mathrm{K}-\mathrm{ABC}$ の結果を分析したもので、具体的な指導 と結びつけた研究はみられない。しかしながら、最近 の $\mathrm{K}-\mathrm{ABC} に お け る$ 研究対象が、学習障害児から他の 障害児へと変わってきたことは、 $\mathrm{K}-\mathrm{ABC}$ の研究が基 礎的な研究から応用的な研究へと変わりつつある重要 なポイントとなるであろう。

\section{V.おわりに}

本研究は、日本版 $\mathrm{K}-\mathrm{ABC}$ の有効活用をめざすため に、アメリカでの $\mathrm{K}-\mathrm{ABC}$ の活用状況や研究状況を把 握することを第 1 の目的として行なってきた。その結 果、 $\mathrm{K}-\mathrm{ABC}$ の妥当性や信頼性といった心理測定に関 する統計学的な研究が数多くなされ、従来の知能テス 卜とは異なる新しい心理検査として認められる様に なっていることが確認できた。しかしその反面、K -ABC の指導における活用に関する研究が少なく、ま た障等児への適用も学習障害児が辰とんどで、他の障 害に適用した研究はまだ数少ないことも明らかとなっ た。しかし幸いなことに、わが国ではカリフォルニア 州にみられるような、知能テストの実施に対する法的 な制限もなく、指導を行なう教師自らが $\mathrm{K}-\mathrm{ABC}$ ，実 施することができる。こうした状況から、 $\mathrm{K}-\mathrm{ABC}$ の 「指導に直結した診断」という発想は、わが国の教育 現場でこそより可能なものであり、日本版 $\mathrm{K}-\mathrm{ABC}$ の これからの活用がさらに期待されるところである。

\section{文 献}

1) Blount, B. S. and Whorton, J. E. (1990) Comparison of $\mathrm{K}-\mathrm{ABC}$ (Achievement Scale) and the Basic Achievement Skills. Psychological Reports, 67, 592-594.

2) Bracken, B. A., Howell, K. K., Harrison, T. E., Stanford, L. D. and Zahn, B. H. (1991) Ipsative subtest pattern stability of the Bracken Basic Concept Scale and the $\mathrm{K}-\mathrm{ABC}$ in a preschool sample. School Psychology Review, 20, 315330.

3) Bracken, B. A. (1987) Limitations of preschool instruments and standards for minimal levels of technical adequacy. Journal of Psychoeducational Assessment, 5, 313-326.

4) Donder, J. (1992) Validity of the K-ABC when employed with children with traumatic brain injury. Journal of Clinical Psychology, 48, 225230.

5) Gibbins, S. (1989) Use of the WISC-R Performance Scale and $\mathrm{K}-\mathrm{ABC}$ Nonverbal Scale with deaf children in the USA and Scotland. School Psychology International, 10, 193-197.

6) Good, R. H. and Lane, S. (1990) Confirmatory factor analysis of the $\mathrm{K}-\mathrm{ABC}$ and WISC-R for at-risk student: A comparison of hierarchical models. School Psychology Review, 19, 492504.

7) Grant, M. L., Ilai, D., Nussbaum, N. L., and Bigler, E. D. (1990) The relationship between continuous performance task and neuropsychological tests in children with Attention Deficit Hyperactivity Disorder. Perceptual and Motor Skills, 70, 435-445.

8) Harrington, R. S., Mcvey, D. and Follett, G. M. (1985) The reliability of the spatial memory subtest of the $\mathrm{K}-\mathrm{ABC}$. Psychology in the Schools, 22, 250-253.

9) Heath, C. P. and Obrzut, J. E. (1988) An investigation of the K-ABC, WISC-R and the Woodcock- Johnson Psychoeducational Battery Part Two with learning disabled children. Psychology in the Schools, 25, 358-364.

10) Hernandez, A. E. and Willson, V. (1992) A comparison of $\mathrm{K}-\mathrm{ABC}$ reliability for Mexican- 
American and non-Hispanic Whites. Hispanic Journal of Behavioral Sciences, 14. 394-397.

11) Hendershott, J. L., Seright, H. R., Hatfield, J. L. and Rogers, B. J. (1990) Correlation between the Stanford-Binet fourth edition and the $\mathrm{K}-\mathrm{ABC}$ for a preschool sample. Perceptual and Motor Skills, 71, 819-825.

12) Hooper, S. R., Brown, L. A. and D'Elia. F. A. (1988) A comparison of the $\mathrm{K}-\mathrm{ABC}$ with the Woodcock-Johnson Test of Academic Achievement in a referred population. Journal of Psychoeducational Assessment, 6, 67-77.

13) Hooper, S. R. (1987) The relationship between the $\mathrm{K}-\mathrm{ABC}$ and the Stanford Binet Achievement Test with reading disabled children. Journal of Psychoeducational Assessment, 5, 401-410.

14) Kamphaus, R. W. and Kaufman, A. S. (1986) Factor analysis of the $\mathrm{K}-\mathrm{ABC}$ for separate groups of boys and girls. Journal of Clinical Child Psychology, 15, 210-213.

15) Kaufman, A. S. (1993) Joint exploratory factor analysis of the $\mathrm{K}-\mathrm{ABC}$ and the KAIT for 11and 12-year-olds. Journal of Clinical Child Psychology, 22, 355-364.

16) Kaufman, A. S. and McLean, J. E. (1987) Joint factor analysis of the $\mathrm{K}-\mathrm{ABC}$ and WISC-R with normal children. Journal of School Psychology, $25,105-118$.

17) Kaufman, A. S. and McLean, J. E. (1986) K$\mathrm{ABC} /$ WISC-R factor analysis for a learning disabled population. Journal of Learning Disabilities, 19, 145-153.

18) Kaufman, A. S. and Kamphaus, R. W. (1984) Factor analysis of the $\mathrm{K}-\mathrm{ABC}$ for age $2 \frac{1}{2}$ through $121 / 2$ years. Journal of Educational Psychology, 76, 623-637.

19) Keith, T. Z. and Novak, C. G. (1987) Joint factor structure of the WISC-R and $K-A B C$. for referred school children. Journal of Psychoeducational Assessment, 5, 370-386.

20) Keith, T. Z. (1986) Factor structure of the K-ABC for referred school children. Psychology in the Schools, 23, 241-246.

21) Keith, T. Z. and Dunbar, S. B. (1984) Hierarchical factor analysis of the $\mathrm{K}-\mathrm{ABC}$ : Testing alternate models. The Journal of Special Education, 18, $367-376$.

22) Klanderman, J. W., Perney, J. and Kroeschell. Z. B. (1985) Comparison of the $\mathrm{K}-\mathrm{ABC}$ and WISC- R for LD children. Journal of Learning Disabilities, 18, 524-527.

23) Lamp. R. E. and Krohn, E. J. (1990) Stability of Stanford-Binet Fourth Edition and $\mathrm{K}-\mathrm{ABC}$ for young Black and White children from low income families. Journal of Psychoeducational Assessment, 8, 139-149.

24) Lyon, M. A. and Smith, D. K. (1987) Stability of the $\mathrm{K}-\mathrm{ABC}$ for a sample of at-risk preschool children. Psychology in the Schools, 24, 111115.

25) Lyon, M. A. and Smith, D. K. (1986) A comparison of at-risk preschool children's performance on the $\mathrm{K}-\mathrm{ABC}$, McCarthy Scale and StanfordBinet. Journal of Psychoeducational Assess ment, 4, 35-43.

26) Matazow, G. S., Kamphaus, R. W., Stanton, H. C. and Reynolds, C. R. (1991) Reliability of the KABC for Black and White students. Journal of School Psychology, 29, 37-41.

27) Mcloughlin, C. S. and Ellison, C. L. (1984) Comparison of scores for normal preschool children on the Peabody Picture Vocabulary Test Revised and the Achievement Scales of the $\mathrm{K}$ ABC. Psychological Reports, 55, 107-114.

28) Moon, S., Ishikuma, T. and Kaufman, A. S. (1987) Joint factor analysis of the $\mathrm{K}-\mathrm{ABC}$ and McCarthy Scales. Perceptual and Motor Skills, 65, 699-704.

29) Naglieri, J. A. (1986) WISC-R and K-ABC comparison for matched samples of Black and White children. Journal of School Psychology, 24, 81 88.

30) Naglieri, J. A. and Hill, D. S. (1986) Comparison of WISC- $\mathrm{R}$ and $\mathrm{K}-\mathrm{ABC}$ regression lines for academic prediction with Black and White children. Journal of Clinical Child Psychology, 15, 352-355.

31) Naglieri, J. A. and Anderson, D. F. (1985) Comparison of the WISC $-\mathrm{R}$ and $\mathrm{K}-\mathrm{ABC}$ with gifted students. Journal of Psychoeducational Assess- 
ment, 3, 175-179.

32) Naglieri, J. A. (1985) Normal children's performance on the McCarthy Scale, $\mathrm{K}-\mathrm{ABC}$ and Peabody Individual Achievement Test. Journal of Psychoeducational Assessment, 3, 123-129.

33) Naglieri, J. A. (1985) Assessment of mentally retarded children with the $\mathrm{K}-\mathrm{ABC}$. American Journal of Mental Deficiency, 89, 367-371.

34) Rothlisberg, B. A. and Mclntosh, D. E. (1991) Performance of a referred sample on the Stanford-Binet IV and the $\mathrm{K}-\mathrm{ABC}$. Journal of School Psychology, 29, 367-370.

35) Saklofske, D. H. (1985) The relationship between Eysenck's major personality dimensions and simultaneous and sequential processing in children. Personality and Individual Differences, 6, 429-433.

36) Siegel, D. J. and Piotrowski, R. J. (1985) Reliability of $\mathrm{K}-\mathrm{ABC}$ subtest composites. Journal of Psychoeducational Assessment, 3, 73-76.

37) Smith, D. P., St. Martin, M. E. and Lyon, M. A. (1989) A validity study of the Stanford-Binet: Fourth edition with students with learning disabilities. Journal of Learning Disabilities, 22,
260-261.

38) Smith, D. K., Bolin. J. A. and Stovall, D. L. (1988) $\mathrm{K}-\mathrm{ABC}$ stability in a preschool sample : A longitudinal study. Journal of Psychoeducational Assessment, 6, 396-403.

39) Strommen, E. (1988) Confirmatory factor analysis of the $\mathrm{K}-\mathrm{ABC}$ : A reevaluation. Journal of School Psychology, 26, 13-23.

40) Valencia, R. R. and Rankin, R. J. (1988) Evidence of bias in predictive validity on the $\mathrm{K}-\mathrm{ABC}$ for children in samples of Anglo and Mexican American children. Psychology in the Schools, $25,257-263$.

$41)$ Willson, V. L., Reynolds, C. R., Chatman, S. P. and Kaufman, A. S. (1985) Confirmatory analysis of simultaneous, sequential and achievement factor on the $\mathrm{K}-\mathrm{ABC}$ at large levels ranging from $21 / 2$ to $12 \frac{1}{2}$ years. Journal of School Psychology, 23, 261-269.

42) Zucker, S. and Riordan, J. (1988) Concurrent validity of new and revised conceptual language measures. Psychology in the Schools, 25, 252 $-256$.

- 1995.5.22. 受稿, 1995.6.27. 受理 — 